\title{
Article \\ Evaluating the Optimal External Equity Financing Strategy and Critical Factors for the Startup of Lending Company in Taiwan: An Application of Expert Network Decision Model
}

\author{
Chun-Yueh Lin ${ }^{1}$ and Yi-Hsien Wang ${ }^{2, *(1)}$ \\ 1 Department of Public Finance and Tax Administration, National Taipei University of Business, No. 321, Sec. 1, \\ Jinan Rd., Zhongzheng District, Taipei 100, Taiwan; ljy898@ntub.edu.tw \\ 2 Department of Banking and Finance, Chinese Culture University, 55, Hwa-Kang Road, Yang-Ming-Shan, \\ Taipei 111, Taiwan \\ * Correspondence: wyx12@ulive.pccu.edu.tw
}

check for updates

Citation: Lin, C.-Y.; Wang, Y.-H. Evaluating the Optimal External Equity Financing Strategy and Critical Factors for the Startup of Lending Company in Taiwan: An Application of Expert Network Decision Model. Mathematics 2021, 9 , 2239. https://doi.org/10.3390/ math9182239

Academic Editors: Violeta Kersuliene and Zenonas Turskis

Received: 14 July 2021

Accepted: 8 September 2021

Published: 12 September 2021

Publisher's Note: MDPI stays neutral with regard to jurisdictional claims in published maps and institutional affiliations.

Copyright: (c) 2021 by the authors. Licensee MDPI, Basel, Switzerland. This article is an open access article distributed under the terms and conditions of the Creative Commons Attribution (CC BY) license (https:/ / creativecommons.org/licenses/by/ $4.0 /)$.

\begin{abstract}
During enterprise foundation and development, internal finance and debt finance are of vital importance to start-up entrepreneurs. Therefore, the purpose of this study is mainly to focus on how start-ups can make the optimal evaluation among different external equity crowdfunding solutions and to establish a network decision support model that evaluates the optimal financing solution of start-ups for external equity crowdfunding based on decision science and network architecture. The Lending Company in Financial Technology Industry (LCFTI) was taken as an example. The results indicate that equity crowdfunding is the optimal financing plan in LCFTI. Academically, the results of this study not only help propose a network decision support model using decision science methods and implementing the network analysis to establish an architecture to evaluate the optimal financing plans of start-ups for external equity crowdfunding, they also makes up for the gap in the optimal financing plans of entrepreneurs or start-ups for external equity financing, which has not been specified in the POT theory in the past. Practically, this study provides a useful tool for the entrepreneur of LCFTI to understand the key factors affecting the optimal financing plans for external equity financing and enables LCFTI to measure the optimal financing plans for external equity financing to improve the success rate of finance.
\end{abstract}

Keywords: network decision support model; crowdfunding; POT theory; external equity financing; analytic network process; start-ups

\section{Introduction}

During enterprise foundation and development, internal finance and debt finance are of vital importance to start-up entrepreneurs [1,2]. Myers (1984) elaborated the pecking order theory (POT) and explained that enterprises prefer to use internal finance when raising capital in order to reduce trading costs and resolve information asymmetry and seek debt finance first in the case of shortage [3]. They will consider offering equity to close the capital gap only when their debt limits are exhausted. Many studies have also demonstrated that the financing order is consistent with the POT theory when start-ups are short of funds in the preliminary stage $[4,5]$. The POT theory explains enterprises' order of financing, however start-ups are unable to raise capital effectively and successfully due to a shortage of it, insufficient enterprise value, and poor finance capability in finance; thus, there is still the dilemma of insufficient capital [6,7].

There is also other evidence that runs contrary to the POT theory, showing that startups shall seek external finance first and conform to the traditional POT channel when raising capital [8,9]. Previous studies have also demonstrated that, because start-ups often run into capital constraints, the availability of external finance is more beneficial for them $[10,11]$. Moreover, most verifications of the POT theory focus on the relationship 
between cash flow and internal finance or external finance [12,13]. Vaznyte \& Andries (2019) verified the relation between start-ups' strategies and POT theory [2], showing results that start-ups with low entrepreneurial orientation are more likely to follow the traditional POT financing order and that start-ups with high entrepreneurial orientation are more inclined to the relationships among equity finance, capital structure and POT theory $[14,15]$. The above literature demonstrates the relationship between several variables and the POT theory. However, it fails to present opinions on the types of external finance and optimal financing solutions to external finance for start-ups. Walthoff-Borm et al. (2018) indicated that enterprises' external finance modes include equity-crowdfunding (EC), angel fund (AF), and venture capital (VC) [16].

Due to the rise of financial technology (fintech) and the loosening of the Jumpstart Our Business Startups (JOBS) Act of the United States [17], crowdfunding has become the latest finance mechanism for enterprises when external capital is needed $[16,18]$. In 2014, the amount raised through crowdfunding reached 16.2 billion USD, increasing $167 \%$ over 2013 [19]. According to the statistics of Statista Inc. [20], the total trading volume of alternative financing is 11.7 billion USD, the expected annual total trading growth rate (2019-2023) is $14.3 \%$, and the total trading volume by 2023 will be 20.0 billion USD. As the largest market share is crowdfunding, the development scale of its market is rapidly rising within the global financial market.

There are many different forms of crowdfunding. First, donation-based crowdfunding refers to collecting charity capital to support project plans. Second, rewards-based crowdfunding refers to investors receiving non-monetary rewards in exchange for sponsors' contributions. Third, debt-based crowdfunding means that the interest measures of investors and fundraisers are formulated through credit contracts. Fourth, equity-based crowdfunding refers to fundraisers offering equity of the target company in exchange for capital and investors receive the corresponding equity so as to obtain the company's subsequent profits or dividends [21-24]. Among them, equity-crowdfunding has been a new solution for start-ups for external equity financing, and this financing solution has become more and more important to them. Equity-crowdfunding provides new investment opportunities for external equity investors [16,25-27].

In equity-crowdfunding, Estrin et al. (2016) proposed that capital is mainly raised via the Internet or social media, which not only reduces trading costs, but also provides a new mechanism for start-ups to establish their goodwill toward investors [28]. Agrawal et al. (2011) argued that start-ups' financing demands and supplies can be matched to all regions more widely via equity-crowdfunding, which is less affected by geographical location [29]. Given that early start-ups tend to be relational in financing, which not only contains hidden biases, but also has a rather narrow range of financing, the equity-crowdfunding (EC) is one of the important tools of external finance for start-ups and has become an important alternative financing solution for them to seek external capital [16,30,31].

Angel funds (AF) mainly refer to the investment in start-ups before going public, which enables them to operate effectively in the early stages; therefore, angel funds have a significant economic impact on the external finance and survival of start-ups [32,33]. Previous studies showed that the market scale of angel investors in the United States was about 24.6 billion USD in 2015 and created 270,200 jobs. The start-ups that have attracted angel funds (AF) had higher survival rates, growth rates, and revenues than those that did not $[34,35]$. Teker \& Teker (2016) indicated that injections in the external finance of start-ups from angel funds are more valuable than those from other financing solutions and also bring experience and professional knowledge to the start-ups to improve the success rates [36]. Dibrova (2015) explained the advantages and disadvantages for start-ups to raise capital by using angel funds, such as: funding to start-ups or high-risk projects, repayment plans with higher flexibility, no need for collateral, unnecessary changes brought by angel fund to enterprises after injections, poor history records of angel fund, and inappropriate exit strategies [37]. Cox et al. (2017) also emphasized that angel funds are crucial for 
start-ups or companies that need external finance. Based on the above, angel funds are one of the alternative financing solutions for start-ups to seek external finance [32].

The main activities of venture capital (VC) are investment, support, exit, and reinvestment [38]. Generally speaking, venture capital comes through the equity holders who participate in the boards of directors of the invested companies in most cases. In addition, venture capital has the ability to influence corporate structures, operating procedures, exit routes, and listing decisions [39]. Companies raise capital through venture capital (VC) of external equity financing and monitoring and value-added services offered by venture capital (VC) can bring positive performance to the companies [40,41]. The current literature also shows that, compared to companies not accepting venture capital investments, companies that do accept venture capital investments can achieve higher employment rates [42,43], higher profitability, more R\&D investments [44], and higher business performances [45]. In view of this, venture capital is a vital alternative financing solution for start-ups to seek external capital.

From the standpoint of entrepreneurs, there are many sources of external finance in the start-up period, and the pecking order theory (POT) is also supported by many studies $[3,4,46]$. There is also evidence showing that the success and failure of a company mainly depends on the financing decisions made in the start-up period $[4,47]$. However, previous studies and reports have not provided any opinion or empirical evidence that entrepreneurs or start-up firms make the optimal choices through equity-crowdfunding or traditional external finance (debt financing) when they need external capital. Moreover, the pecking order theory theoretically does not specify how entrepreneurs or start-ups make the optimal choices among different external equity financing programs (equity-crowdfunding, angel fund, and venture capital) [16,21]. Optimization evaluation is suitable for being introduced into the analytic hierarchy process (AHP) [48], and AHP is also applied to decision evaluation in various fields [49-52]. However, AHP still has the feature that the level and criteria must be independent in decision evaluation, and subsequent studies have broken through the independent features and introduced the concept of network to improve evaluation efficiency. Hence, Saaty (1996) proposed the now widely used analytic network process (ANP) to solve the independence assumption of AHP [53-56].

The purpose of this study is mainly to focus on how start-ups can make the optimal evaluation among different external equity crowdfunding solutions and to establish an expert network decision support model that evaluates the optimal financing solution of start-ups for external equity crowdfunding based on decision science and network architecture. The Lending Company in Financial Technology Industry (LCFTI) was taken as an example. Academically, the results of this study not only help propose a network decision support model using decision science methods and implementing network analysis to establish an architecture to evaluate the optimal financing plans of start-ups for external equity crowdfunding, they also make up for the gap in the optimal financing plans of entrepreneurs or start-ups for external equity financing, which is not specified in the POT theory in the past. Practically, this study provides a useful tool for the entrepreneur of LCFTI to understand the key factors affecting the optimal financing plans for external equity financing and enables LCFTI to measure the optimal financing plans for external equity financing to improve the success rate of finance.

This study is organized into three chapters. We discuss the construction of the expert network decision model in Section 2. An empirical study and the evaluation results appear in Section 3. Finally, Section 4 sets our concluding remarks.

\section{Expert Network Decision Model}

With the optimal financing solution of start-ups for external equity financing, the expert network decision model was proposed by Delphi and ANP. The Delphi method is a popular and useful technique for many applications in decision-making issues [57]. The AHP model is a powerful and popular technique for evaluating the multi-criteria decisionmaking (MCDM) problems. Even though the AHP model is popular, the evidence in the 
field of social sciences has indicated that the characteristics of internal complex correlation in the evaluation of optimal solution issues are unable to be represented satisfactorily with a hierarchical, linear model because of the dependence relationships rather than the up-down relationships. The meaning is that there are network-like relationships $[56,58]$. Hence, the ANP algorithm is proposed to resolve such complex problems as a suitable instrument for implementation in various applications [59-61].

Therefore, this study used the Delphi method and ANP to establish a network decision support model to evaluate the optimal financing solution of start-ups for external equity financing. LCFTI was taken as an example. The study methods are described as follows:

\subsection{Delphi Method}

The Delphi method involves collecting and analyzing opinions of anonymous experts who communicate through writing, discussion, and feedback on particular issues. These anonymous experts share knowledge, skills, expertise, and opinions until they achieve a mutual consensus (Sung 2001). The procedure of the Delphi method is as follows [62]:
A. Select the anonymous experts.
B. Conduct the first round of the survey.
C. Conduct the second round of the questionnaire survey.
D. Conduct the third round of the questionnaire survey.
E. Integrate expert opinions and reach a consensus.

Steps C and D are generally repeated until a consensus is reached regarding a particular topic [63]. Results of the literature review and expert interviews are adopted to identify all common views expressed on this topic. Moreover, step B is simplified to replace the conventionally adopted open style survey; such change is commonly referred to as the modified Delphi method [63]. This study develops a quality evaluation criterion for assessing the optimal financing alternative in external financing activity for start-ups firms. Then, a case study of lending start-ups in the FinTech industry is conducted by using the modified Delphi method and conducting interviews with anonymous experts. In addition, Hasson \& Keeney (2011) indicated that the number of experts should be between five and nine when implementing the Delphi model [64].

\subsection{Analytic Network Process}

Saaty (1996) proposed the analytic network process (ANP), aiming at adding the mechanism of feedback and relation to the analytic hierarchy process, so as to solve the dependence among criteria [56]. The features of the complex relations inside many problems related to decision cannot only be expressed in a hierarchical way, because they are affected mutually, are dependent on each other, and are not linear from top to bottom. This is similar to a network $[56,65,66]$, as shown in Figure 1. ANP consists of four steps, as shown below.

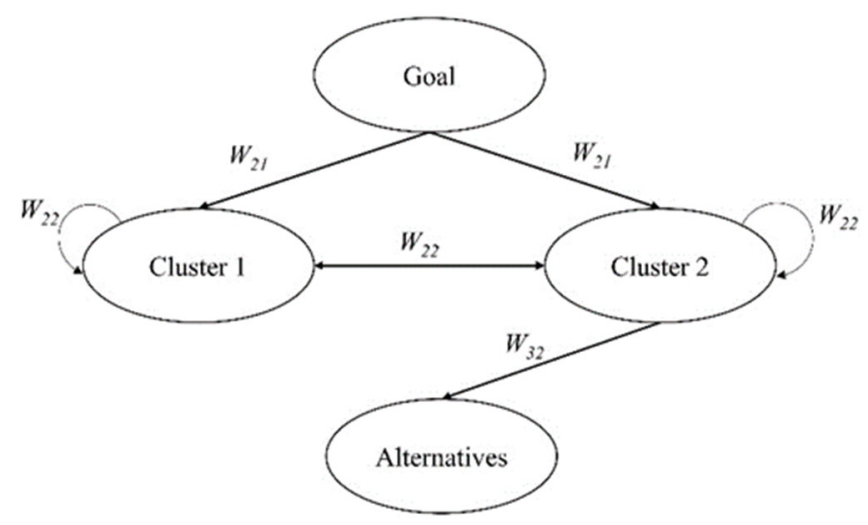

Figure 1. The analytic network process concept. 
Step 1. Network decision support model construction and problem establishment.

The goal is to determine the targets according to the features of problems and seek the decision factors, the sub-factors contained in all factor clusters, and the mutual influence between all factors. If there is mutual influence, it is outer dependence; if the sub-factors contained in all criterion clusters influence each other, it is inner dependence. Finally, overall network structure of the decision problem is drawn.

Step 2. Pairwise comparison matrix structuring and eigenvector calculation.

A pairwise comparison is made between two factors and can be divided into two parts, including the pairwise comparison between all clusters and between sub-factors in clusters. A pairwise comparison between sub-factors can also be divided into that between the same cluster and that between the factors in different clusters. The scale of comparative evaluation is the same as that of the analytic hierarchy orocess, and all comparative matrices were used to obtain the eigenvectors as the value of the supermatrices, so as to illustrate the dependence relationship and relative importance of clusters. Equation (1) can be used in this step to obtain the scores of relative importance among all criteria.

$$
\begin{aligned}
A w & =\lambda \max W \\
\lambda \max & =\sum_{j=1}^{n} a_{i j} \frac{W j}{W i}
\end{aligned}
$$

Here, $A$ is the pairwise comparison matrix of clusters and criteria, $w$ represents eigenvector, and $\lambda$ max refers to the maximum eigenvalue.

Step 3. Supermatrix structuring.

A supermatrix is constituted of all decision factors, as shown in Figure 2. The values in a supermatrix are composed of small matrices, including the comparison between all factors and between dependent factors. The number of the clusters without feedback influence or factors is 0, as shown in Equation (2).

$$
w_{x}=\left[\begin{array}{ccc}
0 & 0 & 0 \\
W_{21} & W_{22} & 0 \\
0 & W_{32} & I
\end{array}\right]
$$

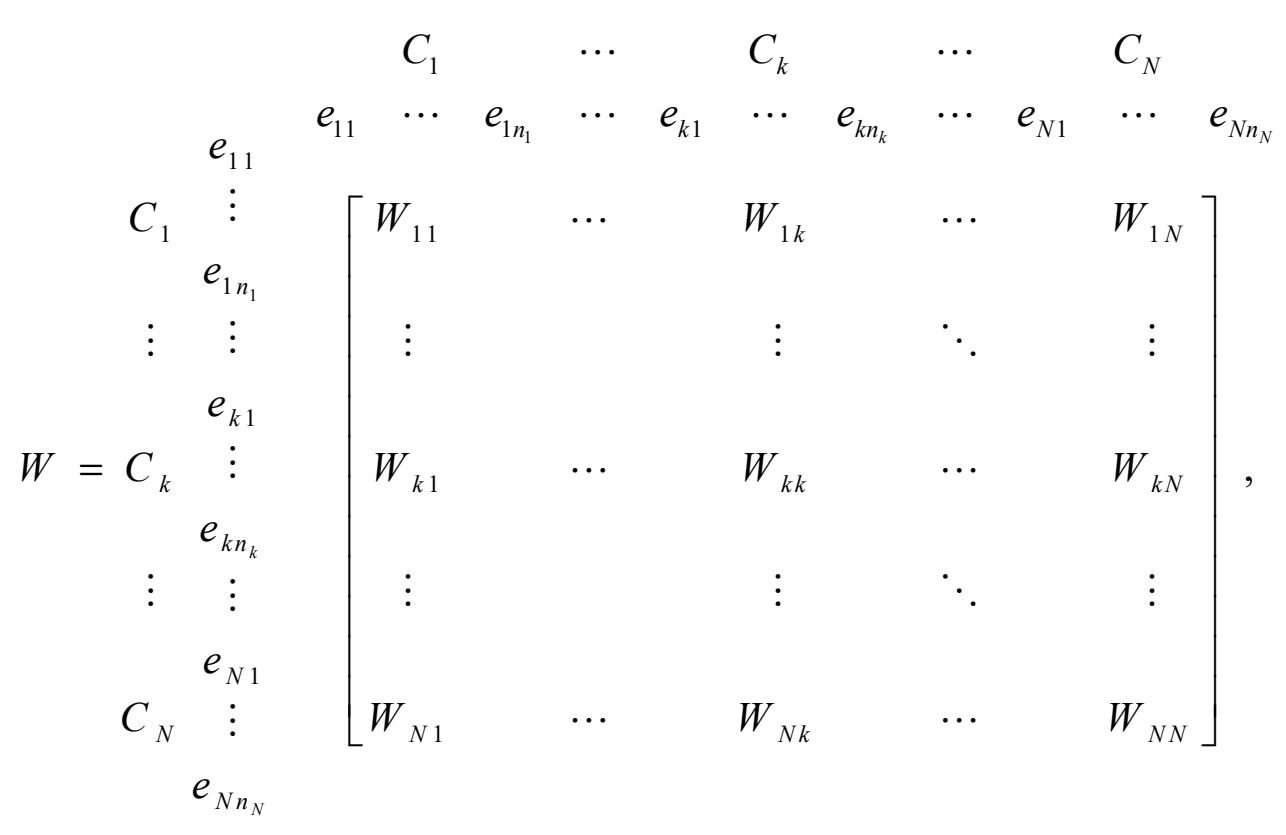

Figure 2. Supermatrix.

The calculation procedure of the analytic network process consists of three matrices: unweighted supermatrix, weighted supermatrix, and limited supermatrix. An unweighted 
supermatrix is derived from the weights of the original pairwise comparisons; a weighted supermatrix refers to multiplying the weights of the same factors in an unweighted supermatrix by the weights of relevant clusters; a limited supermatrix refers to multiplying a weighted matrix by itself for multiple times until the numbers in the fields of all columns are equal. If the supermatrix $\mathrm{w}$ is irreducible in the calculation of the analytic network proposed by Saaty, then all columns in the matrix have the same vector and convergence is achieved. Equation (3) can be used to obtain the final weights of the convergence process.

$$
\lim _{n \rightarrow \infty}(W)^{n}
$$

Step 4. Optimal solution selection.

Verified by the analytic network architecture, unweighted supermatrix, weighted supermatrix, and limited supermatrix, the final weights of all alternative solutions and criteria can be obtained from the results of the limited matrix. The final weights can then be ranked to obtain the optimal solution.

\section{Empirical Study}

The purpose of this study is to establish a network decision support model to evaluate the optimal financing solution of start-ups for external equity crowdfunding, and the Lending Company in Financial Technology Industry (LCFTI) was taken as an example.

The Delphi method was applied in this work which is to collect the elements by a previous literature review and experts' interviews, and utilized a Likert 7-point dimensions for obtaining score, ranging from very unimportant (1) to very important (7). An examination on consistency was calculated by quartile deviation $(Q D)$ to classification the groups after the scores were determined. Deleting the groups with a result of 4.000 or below as well as a $Q D$ of below 1.000; otherwise, it can be retained. Due to the evidence from number of experts should be between five and nine [64]. Therefore, this work utilizes seven experts for obtaining opinions.

As the amount of data is a large set in this study, we employ The Costs of Capital as an example to depict the details. The results of Delphi's' scores in The Costs of Capital of expert 1 to expert 7 are as follows: $6,7,6,6,7,6$, and 6 , respectively. The procedure is as follows: First, evaluate the average important index $(A I I)$ from these outcomes. Second, apply the rank from these set which for a new set is $6,6,6,6,6,7$, and 7 , respectively. Finally, we determine the $Q 1$ and $Q 3$ to obtain the real results of $Q D$. The $Q D$ procedures in The Costs of Capital is as shown below:

$$
\begin{gathered}
A I I=\frac{6+6+6+6+6+7+7}{7}=6.286 \\
Q 1=\frac{7+1}{4}=2=>6 \\
Q 3=\frac{3(7+1)}{4}=6=>7 \\
Q D=\frac{7-6}{2}=0.5
\end{gathered}
$$

The results of $Q D$ in The Costs of Capital element is 0.5. Hence, this element is retained in the expert network decision support model.

The expert network decision support model is shown in Figure 3. Figure 3 is the expert network decision model which comprises three perspectives and 11 elements. The financial perspective includes the elements of the level of loan, the dispersion of equity and the costs of capital. The operational perspective has the elements of the number of board members, the effect of start-ups exposure, the implementation of experts and resources, and the degree of difficulty in capital obtaining. The risk perspective includes the elements of plagiarism, business culture, limitation, and the degree of complexity in crowdfunding. Finally, three alternatives that include equity crowdfunding, an angel fund and venture capital are implemented in this expert network decision support model.

Lastly, the analysis steps, perspectives, and elements of this study are defined as follows. Step 1. Expert network decision model and criterion definition establishment. 
When a study architecture is established, the evaluation criteria shall be agreed upon by experts $[67,68]$. Hence, perspectives and criteria were collected through a literature discussion and expert questionnaires, as shown in Table 1. The modified Delphi method was then used to reach an agreement to obtain the study architecture. Finally, optimal financing plans of start-ups for external equity crowdfunding were evaluated for the perspectives, sub-criterion definitions, and contents as follows.

1. Financial Perspective:

1.1. Level of Loan (LL): can be obtained from different external equity crowdfunding plans by start-ups, such as $\mathrm{EC}, \mathrm{AF}$, and $\mathrm{VC}$.

1.2. Dispersion of Equity (DE): the degree of equity dispersion after start-ups are subscribed by investors.

1.3. Cost of Capital (CC): the costs needed for financing under different external equity crowdfunding plans, such as platform commissions, interests, labor costs, advertising expenses, and administrative charges.

2. Operation Perspective:

2.1. Number of Board Members (MBM): the investors' involvement in the management of start-ups after subscription.

2.2. Effect of Stat-ups Exposure (ESE): the effects on start-ups when financing is conducted through external equity crowdfunding.

2.3. Implementation of Experts and Resources (IER): the differences in professionals and resources introduced after start-ups have obtained finance through different external equity financing plans.

2.4. The Degree of Difficulty in Capital Obtaining (DCO): the different difficulties in finance through different external equity financing plans of start-ups.

3. Risks Perspective:

3.1. Plagiarism (PLA): when start-ups finance through external equity crowdfunding platforms, their know-hows or ideas may be plagiarized or counterfeited.

3.2. Business Culture (BUC): start-ups obtain capital, and investors control the equity and intervene in the corporate business, causing conflict in the management cultures between investors and start-ups.

3.3. Limitation (LIT): investors may have restrictions, such as board seats, control rights, and liquidation preferences, placed on the start-ups after investment.

3.4. Degree of Complexity in Crowdfunding (DCC): different fundraising plans have varying fundraising complexity, which has a great impact on the start-ups' fundraising activities in the earlier stage.

4. External equity financing plans:

4.1. Equity Crowdfunding (EC): fundraisers may raise capital through equitycrowdfunding channels, which denotes that fundraisers may offer equities of the target companies in exchange for capital and investors obtain the corresponding equities to obtain subsequent profits or dividends.

4.2. Angel Fund (AF): fundraisers may raise capital by using angel fund platforms and provide part of the equities in the target companies to obtain injections from an angel fund. Angel investors mainly invest in the start-ups before going public to enable them to operate effectively.

4.3. Venture Capital (VC): fundraisers may raise capital through venture capital channels. Venture capitals are the equity holders who participate in the boards of directors of the invested companies in most cases and who introduce professionals and resources to improve the business performances of start-ups.

Step 2. Pairwise comparison matrix structuring and eigenvector calculation.

A pairwise comparison matrix of AHP was used to measure eigenvectors of all perspectives and criteria, including the eigenvectors of relation dependence. In this study, the network decision support model includes perspectives (such as finance, operations, 
and risks), sub-criteria (such as financing amount, equity structure, fundraising costs, structure of management rights, propaganda effects, crowdfunding threshold, and introduction of professionals and resources), and external equity financing plans (such as equity-crowdfunding, angel funds, and venture capital). The geometric mean method was introduced to calculate the relative scores provided by the expert group for summarization. Table 2 shows the eigenvectors of 3 perspectives (clusters), and Table 3 shows the eigenvectors of 11 sub-criteria.

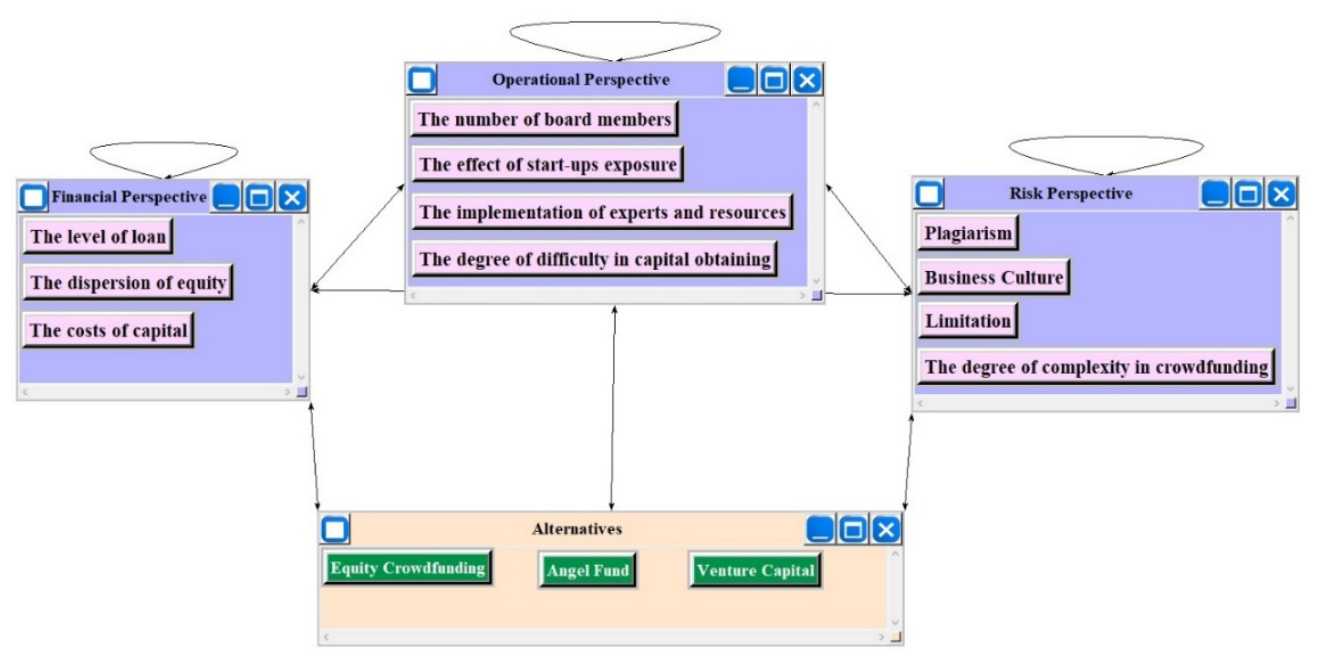

Figure 3. The expert network decision support model.

Table 1. The perspectives and criteria.

\begin{tabular}{|c|c|c|c|}
\hline Goal & Perspectives & Sub-Criteria & Ref. \\
\hline \multirow{8}{*}{$\begin{array}{l}\text { Optimal } \\
\text { Alternative }\end{array}$} & $\begin{array}{l}\text { Financial } \\
\text { Perspective }\end{array}$ & $\begin{array}{l}\text { The level of loan } \\
\text { The dispersion of equity } \\
\text { The costs of capital }\end{array}$ & $\begin{array}{l}\text { Ahlers et al., (2015); } \\
\text { Bessière et al., (2018) } \\
\text { Ahlers et al., (2015); } \\
\text { Signori, \& Vismara (2018); } \\
\text { Rogan \& Sarfati (2018) } \\
\text { Expert suggestion }\end{array}$ \\
\hline & \multirow[t]{3}{*}{$\begin{array}{l}\text { Operational } \\
\text { Perspective }\end{array}$} & $\begin{array}{l}\text { The number of board members } \\
\text { The effect of start-ups exposure }\end{array}$ & $\begin{array}{l}\text { Signori, \& Vismara (2018); } \\
\text { Turan (2015) } \\
\text { Hauge, \& Chimahusky (2016); } \\
\text { Presenza et al., (2019) }\end{array}$ \\
\hline & & $\begin{array}{l}\text { The degree of difficulty in capital } \\
\text { obtaining }\end{array}$ & Bessière et al., (2018) \\
\hline & & $\begin{array}{l}\text { The implementation of experts and } \\
\text { resources }\end{array}$ & $\begin{array}{l}\text { Baum, \& Silverman (2004); } \\
\text { Knockaert et al., (2010) }\end{array}$ \\
\hline & \multirow{4}{*}{$\begin{array}{l}\text { Risk } \\
\text { Perspective }\end{array}$} & Plagiarism & Pazowski \& Czudec (2014) \\
\hline & & Business culture & $\begin{array}{l}\text { Dai \& Nahata (2016); } \\
\text { Nahata et al., (2014) }\end{array}$ \\
\hline & & Limitation & $\begin{array}{l}\text { Kaplan \& Stromberg (2001); } \\
\text { Da Rin et al., (2013); } \\
\text { Rogan \& Sarfati (2018) }\end{array}$ \\
\hline & & $\begin{array}{l}\text { The degree of complexity in } \\
\text { crowdfunding }\end{array}$ & Bessière et al., (2018) \\
\hline
\end{tabular}

Step 3. Supermatrix structuring.

According to the expert group's suggestions and questionnaire results, the inner dependence relation and outer dependence relation of the network decision support model of the optima financing plan of start-ups for external equity financing can be descried, and an unweighted supermatrix and a weighted supermatrix were formed through the 
eigenvector results. A limitation was then conducted on the weighted supermatrix to obtain a limited supermatrix, as shown in Tables A1-A4 (In Appendix A).

Table 2. The comparisons and eigenvectors (weights) of 3 perspectives.

\begin{tabular}{cccc}
\hline & $\begin{array}{c}\text { Financial } \\
\text { Perspective }\end{array}$ & $\begin{array}{c}\text { Operational } \\
\text { Perspective }\end{array}$ & $\begin{array}{c}\text { Risk } \\
\text { Perspective }\end{array}$ \\
\hline $\begin{array}{c}\text { Financial } \\
\text { Perspective }\end{array}$ & 1.000 & 1.248 & 1.462 \\
$\begin{array}{c}\text { Operational } \\
\text { Perspective } \\
\text { Risk }\end{array}$ & 0.801 & 1.000 & 1.171 \\
$\begin{array}{c}\text { Perspective } \\
\text { Eigenvectors } \\
\text { (weights) }\end{array}$ & 0.684 & 0.854 & 1.000 \\
\hline
\end{tabular}

Table 3. Eigenvectors (weights) of 11 factors for alternatives.

\begin{tabular}{cccc}
\hline & $\begin{array}{c}\text { Angel } \\
\text { Fund }\end{array}$ & $\begin{array}{c}\text { Equity } \\
\text { Crowdfunding }\end{array}$ & $\begin{array}{c}\text { Venture } \\
\text { Capital }\end{array}$ \\
\hline CC & 0.447 & 0.462 & 0.091 \\
DE & 0.403 & 0.398 & 0.199 \\
LL & 0.389 & 0.413 & 0.198 \\
DCO & 0.397 & 0.408 & 0.195 \\
ESE & 0.413 & 0.386 & 0.201 \\
IER & 0.422 & 0.366 & 0.212 \\
MBM & 0.383 & 0.398 & 0.219 \\
BUC & 0.421 & 0.366 & 0.213 \\
DCC & 0.365 & 0.399 & 0.236 \\
LIT & 0.313 & 0.438 & 0.249 \\
PLA & 0.388 & 0.353 & 0.259 \\
\hline
\end{tabular}

Step 4. Optimal solution selection.

After the calculation of the above supermatrix, the weights of the dependence relations of all evaluation criteria and plans can be obtained, as shown in Table 4. Next, the comprehensive weights were used for ranking, the order of the optimal plans is EC (0.082) $>\mathrm{AF}(0.078)>\mathrm{VC}(0.040)$, and the order of the evaluation criteria is LL $(0.107)>\mathrm{DCO}$ $(0.106)>\mathrm{CC}(0.104)>\operatorname{LIT}(0.096)>\operatorname{DCC}(0.085)>\operatorname{MBM}(0.078)>\operatorname{DE}(0.070)>\operatorname{DSE}(0.049)>$ PLA (0.042) > BUC (0.032) > IER (0.031). The results show that the start-up of LCFTI should adopt equity-crowdfunding as the optimal financing channel in the earlier stage and the most important factor is LL.

Table 4. The priorities of criteria and alternatives.

\begin{tabular}{cccc}
\hline & Normalized by Cluster & Limiting & Rank \\
\hline Angel Fund & 0.391 & 0.078 & 2 \\
Equity Crowdfunding & 0.409 & 0.082 & 1 \\
Venture Capital & 0.201 & 0.040 & 3 \\
\hline CC & 0.369 & 0.104 & 7 \\
DE & 0.248 & 0.070 & 1 \\
LL & 0.383 & 0.107 & 2 \\
DCO & 0.401 & 0.106 & 8 \\
ESE & 0.187 & 0.049 & 11 \\
IER & 0.118 & 0.031 & 6 \\
MBM & 0.294 & 0.078 & 10 \\
BUC & 0.126 & 0.032 & 5 \\
DCC & 0.333 & 0.085 & 4 \\
LIT & 0.376 & 0.096 & 9 \\
PLA & 0.165 & 0.042 & \\
\hline
\end{tabular}




\section{Discussion}

Based on the proposed expert network decision support model, the results of the evaluation criteria indicate that LL, DCO, and CC are the most crucial factors affecting LCFTI to evaluate the optimal financing plan when fundraising. Moreover, LCFTI highly values the financing amount, difficulty of obtaining capital, and fundraising costs for external equity financing. Start-ups need a large amount of capital in the earlier stage, and hence the financing amount and financing difficulty are quite close in the critical importance score. This means that the financing amount and financing success when the start-up LCFTI evaluates the optimal financing plan for external equity crowdfunding has an impact on the operation efficiency of the company. For instance, if a start-up needs capital or a small financing amount, or capital is raised successfully but cannot obtained rapidly, then this may cause great risk to the operation of the start-up in the earlier stage. In addition, since start-ups own quite limited capital in the earlier stage, the fundraising will increase the operating costs (including accounting fees, counsel fees, and audit fees) of start-ups for external equity crowdfunding. From the perspective of risks, the most critical factor is LIT, showing that start-ups may be influenced by investors' policies, such as board seats, corporate control rights, and liquidation preferences, and restrictive terms may be established for the entrepreneurs when capital is obtained through external equity crowdfunding, which is contrary to the original idea of start-ups. Hence, the start-up LCFTI should carefully consider the issue of fundraising costs when selecting the optimal financing plan for external equity crowdfunding and also consider the risks caused by limitations to operations and management. Overall, the results of this study which the optimal external equity financing strategy for start-ups of LCFTI in Taiwan is Equity Crowdfunding. This outcome is consistent with the previous evidence that the equity crowdfunding strategy with its growing role for startups financing as well as equity crowdfunding also has gained momentum in the academic community [69-72]. Moreover, Hornuf et al. (2018) and Signori \& Vismara (2018) find that companies that obtained the equity crowdfunding register a higher change of obtaining follow-on financing via business angels or venture capitalists [73,74].

\section{Conclusions}

During enterprise foundation and development, internal finance and debt finance are of vital importance to start-up entrepreneurs. The pecking order theory explains that enterprises prefer to use internal finance when raising capital in order to reduce trading costs and solve information asymmetry and will seek debt finance first in case of cash flow shortage. They will consider offering equity to close the capital gap only when debt limits are exhausted. In spite of this, in recent years, due to the rise of financial technology (fintech) and the loosening of the Jumpstart Our Business Startups (JOBS) Act of the United States, external equity crowdfunding has become the latest finance mechanism for enterprises when external capital is needed. Moreover, equity-crowdfunding is a new solution of start-ups for external equity financing, and this financing solution has become more and more important to them. Equity-crowdfunding provides new investment opportunities for external equity investors. Generally speaking, external financing solutions include equitycrowdfunding, angel fund, and venture capital, with different features and purposes. The pecking order theory does not put forward opinions to start-ups on the optimal financing plans for seeking external equity crowdfunding. Therefore, which optimal financing plan start-ups shall use to raise their working capital when conducting external equity crowdfunding is a key problem to solve for entrepreneurs.

This study therefore mainly focuses on how start-ups can make the optimal choice among different external equity crowdfunding solutions and establishes a network decision support model to evaluate the optimal financing solution of start-ups for external equity crowdfunding based on decision science and network architecture. The Lending Company in Financial Technology Industry (LCFTI) was taken as an example. The study results show that the optimal financial plan of LCFTI is equity crowdfunding. As an emerging financial 
technology company, LCFTI mainly profits from online lending. Hence, lending platforms' goodwill, reputation, and popularity are rather important to its investors. Due to the large number of potential investors faced by equity crowdfunding, it is easier for LCFTI to obtain capital through equity crowdfunding platforms than through angel funding and venture capital. Furthermore, through equity crowdfunding platforms, it can also increase its popularity and boost the trading volumes of loans, so that the operation structure of LCFTI can become stronger.

With LCFTI as an example, this study proposed a network decision support model of optimal financial plans for start-ups to conduct external equity crowdfunding. Academically, the results of this study not only help propose a network decision support model using decision science methods and implement the network analysis to establish an architecture to evaluate the optimal financing plans of start-ups for external equity crowdfunding, but also make up for the gap in the optimal financing plans of entrepreneurs or start-ups for external equity financing, which is not specified in the POT theory in the past. Practically, this study presents a useful tool for the entrepreneurs of LCFTI to understand the key factors affecting their firm's optimal financing plans for external equity financing and also enables LCFTI to measure the optimal financing plans for external equity financing to improve the success rate of financing.

This work has a several limitations and suggestions from some views, as give below:

1. Uncertainty of humans: This study implements the modified Delphi method and the ANP for determining the optimal financing plan. However, the proposed expert network decision support models are not concerned about the ambiguous nature of humans. Therefore, future works are able to combine the fuzzy concepts in the evaluation model construction.

2. Investors' view: This study was implemented by expert opinions for evaluating the optimal external financing strategy. Hence, future studies can apply the investors' view to assess the optimal start-up based on the results of this study.

3. Samples of survey: To reduce the complex evaluation procedures, this study was based on the experts view to determine the optimal solution. Thus, future studies can carry out with the larger sample to identify the optimal solution in this field.

The future works are able to extend the limitations and suggestions of this work for developing a new evaluation framework.

Author Contributions: Data curation, Y.-H.W.; Investigation, Y.-H.W.; Methodology, C.-Y.L.; Software, C.-Y.L. All authors have read and agreed to the published version of the manuscript.

Funding: This research received no external funding.

Institutional Review Board Statement: Not applicable.

Informed Consent Statement: Not applicable.

Data Availability Statement: Not applicable.

Acknowledgments: We would like to thank the reviewers and An-Chi Wu for their valuable comments, which helps us to improve the manuscript.

Conflicts of Interest: The authors declare no conflict of interest. 
Appendix A

Table A1. Inner dependence matrix of 11 factors.

\begin{tabular}{cccccccccccc}
\hline & CC & DE & LL & DCO & ESE & IER & MBM & BUC & DCC & LIT & PLA \\
\hline CC & 0.000 & 0.367 & 0.419 & 0.417 & 0.388 & 0.356 & 0.413 & 0.362 & 0.413 & 0.483 & 0.393 \\
DE & 0.392 & 0.000 & 0.581 & 0.254 & 0.207 & 0.239 & 0.176 & 0.302 & 0.196 & 0.202 & 0.236 \\
LL & 0.608 & 0.633 & 0.000 & 0.329 & 0.405 & 0.405 & 0.411 & 0.336 & 0.391 & 0.315 & 0.371 \\
DCO & 0.373 & 0.403 & 0.511 & 0.000 & 0.409 & 0.498 & 0.573 & 0.492 & 0.506 & 0.386 & 0.473 \\
ESE & 0.197 & 0.152 & 0.112 & 0.312 & 0.000 & 0.211 & 0.255 & 0.184 & 0.198 & 0.184 & 0.162 \\
IER & 0.082 & 0.106 & 0.096 & 0.266 & 0.176 & 0.000 & 0.172 & 0.093 & 0.093 & 0.082 & 0.101 \\
MBM & 0.348 & 0.339 & 0.281 & 0.422 & 0.415 & 0.291 & 0.000 & 0.231 & 0.203 & 0.348 & 0.264 \\
BUC & 0.061 & 0.079 & 0.107 & 0.071 & 0.084 & 0.103 & 0.091 & 0.000 & 0.157 & 0.386 & 0.266 \\
DCC & 0.368 & 0.418 & 0.411 & 0.396 & 0.407 & 0.364 & 0.378 & 0.355 & 0.000 & 0.281 & 0.283 \\
LIT & 0.409 & 0.471 & 0.398 & 0.419 & 0.451 & 0.389 & 0.367 & 0.383 & 0.432 & 0.000 & 0.451 \\
PLA & 0.162 & 0.032 & 0.084 & 0.114 & 0.058 & 0.144 & 0.164 & 0.262 & 0.411 & 0.333 & 0.000 \\
\hline
\end{tabular}

Table A2. The unweighted supermatrix.

\begin{tabular}{|c|c|c|c|c|c|c|c|c|c|c|c|c|c|c|}
\hline & $\mathrm{AF}$ & EC & VC & $\mathrm{CC}$ & DE & LL & DCO & ESE & IER & MBM & BUC & DCC & LIT & PLA \\
\hline $\mathrm{AF}$ & 0.000 & 0.000 & 0.000 & 0.447 & 0.403 & 0.389 & 0.397 & 0.413 & 0.422 & 0.383 & 0.421 & 0.365 & 0.313 & 0.388 \\
\hline $\mathrm{EC}$ & 0.000 & 0.000 & 0.000 & 0.462 & 0.398 & 0.413 & 0.408 & 0.386 & 0.366 & 0.398 & 0.366 & 0.399 & 0.438 & 0.353 \\
\hline VC & 0.000 & 0.000 & 0.000 & 0.091 & 0.199 & 0.198 & 0.195 & 0.201 & 0.212 & 0.219 & 0.213 & 0.236 & 0.249 & 0.259 \\
\hline $\mathrm{CC}$ & 0.353 & 0.447 & 0.377 & 0.000 & 0.367 & 0.419 & 0.417 & 0.388 & 0.356 & 0.413 & 0.362 & 0.413 & 0.483 & 0.393 \\
\hline $\mathrm{DE}$ & 0.281 & 0.105 & 0.189 & 0.392 & 0.000 & 0.581 & 0.254 & 0.207 & 0.239 & 0.176 & 0.302 & 0.196 & 0.202 & 0.236 \\
\hline LL & 0.366 & 0.449 & 0.434 & 0.608 & 0.633 & 0.000 & 0.329 & 0.405 & 0.405 & 0.411 & 0.336 & 0.391 & 0.315 & 0.371 \\
\hline $\mathrm{DCO}$ & 0.337 & 0.487 & 0.406 & 0.373 & 0.403 & 0.511 & 0.000 & 0.409 & 0.498 & 0.573 & 0.492 & 0.506 & 0.386 & 0.473 \\
\hline ESE & 0.255 & 0.103 & 0.214 & 0.197 & 0.152 & 0.112 & 0.312 & 0.000 & 0.211 & 0.255 & 0.184 & 0.198 & 0.184 & 0.162 \\
\hline IER & 0.112 & 0.088 & 0.101 & 0.082 & 0.106 & 0.096 & 0.266 & 0.176 & 0.000 & 0.172 & 0.093 & 0.093 & 0.082 & 0.101 \\
\hline MBM & 0.296 & 0.322 & 0.279 & 0.348 & 0.339 & 0.281 & 0.422 & 0.415 & 0.291 & 0.000 & 0.231 & 0.203 & 0.348 & 0.264 \\
\hline BUC & 0.098 & 0.114 & 0.072 & 0.061 & 0.079 & 0.107 & 0.071 & 0.084 & 0.103 & 0.091 & 0.000 & 0.157 & 0.386 & 0.266 \\
\hline DCC & 0.367 & 0.301 & 0.388 & 0.368 & 0.418 & 0.411 & 0.396 & 0.407 & 0.364 & 0.378 & 0.355 & 0.000 & 0.281 & 0.283 \\
\hline LIT & 0.412 & 0.396 & 0.431 & 0.409 & 0.471 & 0.398 & 0.419 & 0.451 & 0.389 & 0.367 & 0.383 & 0.432 & 0.000 & 0.451 \\
\hline PLA & 0.123 & 0.189 & 0.109 & 0.162 & 0.032 & 0.084 & 0.114 & 0.058 & 0.144 & 0.164 & 0.262 & 0.411 & 0.333 & 0.000 \\
\hline
\end{tabular}

Table A3. The weighted supermatrix.

\begin{tabular}{|c|c|c|c|c|c|c|c|c|c|c|c|c|c|c|}
\hline & AF & EC & VC & $\mathrm{CC}$ & DE & LL & DCO & ESE & IER & MBM & BUC & DCC & LIT & PLA \\
\hline $\mathrm{AF}$ & 0.000 & 0.000 & 0.000 & 0.112 & 0.101 & 0.097 & 0.099 & 0.103 & 0.106 & 0.096 & 0.105 & 0.091 & 0.078 & 0.097 \\
\hline $\mathrm{EC}$ & 0.000 & 0.000 & 0.000 & 0.116 & 0.100 & 0.103 & 0.102 & 0.097 & 0.092 & 0.100 & 0.092 & 0.100 & 0.110 & 0.088 \\
\hline VC & 0.000 & 0.000 & 0.000 & 0.023 & 0.050 & 0.050 & 0.049 & 0.050 & 0.053 & 0.055 & 0.053 & 0.059 & 0.062 & 0.065 \\
\hline $\mathrm{CC}$ & 0.142 & 0.180 & 0.152 & 0.000 & 0.092 & 0.105 & 0.104 & 0.097 & 0.089 & 0.103 & 0.091 & 0.103 & 0.121 & 0.098 \\
\hline $\mathrm{DE}$ & 0.113 & 0.042 & 0.076 & 0.098 & 0.000 & 0.145 & 0.064 & 0.052 & 0.060 & 0.044 & 0.076 & 0.049 & 0.051 & 0.059 \\
\hline LL & 0.147 & 0.181 & 0.175 & 0.152 & 0.158 & 0.000 & 0.082 & 0.101 & 0.101 & 0.103 & 0.084 & 0.098 & 0.079 & 0.093 \\
\hline $\mathrm{DCO}$ & 0.109 & 0.157 & 0.131 & 0.093 & 0.101 & 0.128 & 0.000 & 0.102 & 0.125 & 0.143 & 0.123 & 0.127 & 0.097 & 0.118 \\
\hline ESE & 0.082 & 0.033 & 0.069 & 0.049 & 0.038 & 0.028 & 0.078 & 0.000 & 0.053 & 0.064 & 0.046 & 0.050 & 0.046 & 0.041 \\
\hline IER & 0.036 & 0.028 & 0.033 & 0.021 & 0.027 & 0.024 & 0.067 & 0.044 & 0.000 & 0.043 & 0.023 & 0.023 & 0.021 & 0.025 \\
\hline MBM & 0.095 & 0.104 & 0.090 & 0.087 & 0.085 & 0.070 & 0.106 & 0.104 & 0.073 & 0.000 & 0.058 & 0.051 & 0.087 & 0.066 \\
\hline BUC & 0.027 & 0.031 & 0.020 & 0.015 & 0.020 & 0.027 & 0.018 & 0.021 & 0.026 & 0.023 & 0.000 & 0.039 & 0.097 & 0.067 \\
\hline DCC & 0.101 & 0.083 & 0.107 & 0.092 & 0.105 & 0.103 & 0.099 & 0.102 & 0.091 & 0.095 & 0.089 & 0.000 & 0.070 & 0.071 \\
\hline LIT & 0.113 & 0.109 & 0.119 & 0.102 & 0.118 & 0.100 & 0.105 & 0.113 & 0.097 & 0.092 & 0.096 & 0.108 & 0.000 & 0.113 \\
\hline PLA & 0.034 & 0.052 & 0.030 & 0.041 & 0.008 & 0.021 & 0.029 & 0.015 & 0.036 & 0.041 & 0.066 & 0.103 & 0.083 & 0.000 \\
\hline
\end{tabular}


Table A4. The limited supermatrix.

\begin{tabular}{|c|c|c|c|c|c|c|c|c|c|c|c|c|c|c|}
\hline & AF & EC & VC & $\mathrm{CC}$ & DE & LL & DCO & ESE & IER & MBM & BUC & DCC & LIT & PLA \\
\hline $\mathrm{AF}$ & 0.078 & 0.078 & 0.078 & 0.078 & 0.078 & 0.078 & 0.078 & 0.078 & 0.078 & 0.078 & 0.078 & 0.078 & 0.078 & 0.078 \\
\hline $\mathrm{EC}$ & 0.082 & 0.082 & 0.082 & 0.082 & 0.082 & 0.082 & 0.082 & 0.082 & 0.082 & 0.082 & 0.082 & 0.082 & 0.082 & 0.082 \\
\hline VC & 0.040 & 0.040 & 0.040 & 0.040 & 0.040 & 0.040 & 0.040 & 0.040 & 0.040 & 0.040 & 0.040 & 0.040 & 0.040 & 0.040 \\
\hline CC & 0.104 & 0.104 & 0.104 & 0.104 & 0.104 & 0.104 & 0.104 & 0.104 & 0.104 & 0.104 & 0.104 & 0.104 & 0.104 & 0.104 \\
\hline $\mathrm{DE}$ & 0.070 & 0.070 & 0.070 & 0.070 & 0.070 & 0.070 & 0.070 & 0.070 & 0.070 & 0.070 & 0.070 & 0.070 & 0.070 & 0.070 \\
\hline LL & 0.107 & 0.107 & 0.107 & 0.107 & 0.107 & 0.107 & 0.107 & 0.107 & 0.107 & 0.107 & 0.107 & 0.107 & 0.107 & 0.107 \\
\hline $\mathrm{DCO}$ & 0.106 & 0.106 & 0.106 & 0.106 & 0.106 & 0.106 & 0.106 & 0.106 & 0.106 & 0.106 & 0.106 & 0.106 & 0.106 & 0.106 \\
\hline ESE & 0.049 & 0.049 & 0.049 & 0.049 & 0.049 & 0.049 & 0.049 & 0.049 & 0.049 & 0.049 & 0.049 & 0.049 & 0.049 & 0.049 \\
\hline IER & 0.031 & 0.031 & 0.031 & 0.031 & 0.031 & 0.031 & 0.031 & 0.031 & 0.031 & 0.031 & 0.031 & 0.031 & 0.031 & 0.031 \\
\hline MBM & 0.078 & 0.078 & 0.078 & 0.078 & 0.078 & 0.078 & 0.078 & 0.078 & 0.078 & 0.078 & 0.078 & 0.078 & 0.078 & 0.078 \\
\hline BUC & 0.032 & 0.032 & 0.032 & 0.032 & 0.032 & 0.032 & 0.032 & 0.032 & 0.032 & 0.032 & 0.032 & 0.032 & 0.032 & 0.032 \\
\hline DCC & 0.085 & 0.085 & 0.085 & 0.085 & 0.085 & 0.085 & 0.085 & 0.085 & 0.085 & 0.085 & 0.085 & 0.085 & 0.085 & 0.085 \\
\hline LIT & 0.096 & 0.096 & 0.096 & 0.096 & 0.096 & 0.096 & 0.096 & 0.096 & 0.096 & 0.096 & 0.096 & 0.096 & 0.096 & 0.096 \\
\hline PLA & 0.042 & 0.042 & 0.042 & 0.042 & 0.042 & 0.042 & 0.042 & 0.042 & 0.042 & 0.042 & 0.042 & 0.042 & 0.042 & 0.042 \\
\hline
\end{tabular}

\section{References}

1. Cole, R.; Cumming, D.; Li, D. Do banks or VCs spur small firm growth? J. Int. Financ. Mark. Inst. Money 2016, 41, 60-72. [CrossRef]

2. Vaznyte, E.; Andries, P. Entrepreneurial orientation and start-ups' external financing. J. Bus. Ventur. 2019, 34, 439-458. [CrossRef]

3. Myers, S.C. The capital structure puzzle. J. Financ. 1984, 39, 574-592. [CrossRef]

4. Mina, A.; Lahr, H.; Hughes, A. The demand and supply of external finance for innovative firms. Ind. Corp. Chang. 2013, 22, 869-901. [CrossRef]

5. Robb, A.M.; Robinson, D.T. The capital structure decisions of new firms. Rev. Financ. Stud. 2014, 27, 153-179. [CrossRef]

6. Casamatta, C.; Haritchabalet, C. Dealing with venture capitalists: Shopping around or exclusive negotiation. Rev. Financ. 2013, 18, 1743-1773. [CrossRef]

7. Chen, X.P.; Yao, X.; Kotha, S. Entrepreneur passion and preparedness in business plan presentations: A persuasion analysis of venture capitalists' funding decisions. Acad. Manag. J. 2009, 52, 199-214. [CrossRef]

8. Carpenter, R.E.; Petersen, B.C. Capital market imperfections, high-tech investment, and new equity financing. Econ. J. 2002, 112, F54-F72. [CrossRef]

9. Paul, S.; Whittam, G.; Wyper, J. The pecking order hypothesis: Does it apply to start-up firms? J. Small Bus. Enterp. Dev. 2007, 14, 8-21. [CrossRef]

10. Aghion, P.; Fally, T.; Scarpetta, S. Credit constraints as a barrier to the entry and post-entry growth of firms. Econ. Policy 2007, 22, 732-779. [CrossRef]

11. Guiso, L.; Sapienza, P.; Zingales, L. The role of social capital in financial development. Am. Econ. Rev. 2004, 94, 526-556. [CrossRef]

12. Dogru, T.; Sirakaya-Turk, E. The value of cash holdings in hotel firms. Int. J. Hosp. Manag. 2017, 65, 20-28. [CrossRef]

13. Park, J. Financial constraints and the cash flow sensitivities of external financing: Evidence from Korea. Res. Int. Bus. Financ. 2019, 49, 241-250. [CrossRef]

14. Khémiri, W.; Noubbigh, H. Determinants of capital structure: Evidence from sub-Saharan African firms. Q. Rev. Econ. Financ. 2018, 70, 150-159. [CrossRef]

15. Yildirim, R.; Masih, M.; Bacha, O.I. Determinants of capital structure: Evidence from Shari'ah compliant and non-compliant firms. Pacific-Basin Financ. J. 2018, 51, 198-219. [CrossRef]

16. Walthoff-Borm, X.; Schwienbacher, A.; Vanacker, T. Equity crowdfunding: First resort or last resort? J. Bus. Ventur. 2018, 33, 513-533. [CrossRef]

17. Ivanov, V.; Knyazeva, A. US Securities-Based Crowdfunding under Title III of the JOBS Act. DERA White Paper 2017. Available online: https:/ / www.sec.gov /dera/staff-papers/white-papers/28feb17_ivanov-knyazeva_crowdfunding-under-titleiii-jobsact.html (accessed on 15 July 2019).

18. Rossi, M. The new ways to raise capital: An exploratory study of crowdfunding. Int. J. Financ. Res. 2014, 5, 8-18. [CrossRef]

19. Massolution, C.F. The Crowdfunding Industry Report. 2015. Available online: http://www.smv.gob.pe/Biblioteca/temp/ catalogacion/C8789.pdf (accessed on 9 July 2019).

20. Statista. Inc. Alternative Financing Report 2019. Available online: https://www.statista.com/outlook/297/100/alternativefinancing/worldwide (accessed on 9 July 2019).

21. Belleflamme, P.; Lambert, T.; Schwienbacher, A. Crowdfunding: Tapping the right crowd. J. Bus. Ventur. 2014, 29, 585-609. [CrossRef]

22. Cholakova, M.; Clarysse, B. Does the Possibility to Make Equity Investments in Crowdfunding Projects Crowd Out Reward-Based Investments? Entrep. Theory Pract. 2015, 39, 145-172. [CrossRef] 
23. Lu, Y.; Chang, R.; Lim, S. Crowdfunding for solar photovoltaics development: A review and forecast. Renew. Sustain. Energy Rev. 2018, 93, 439-450. [CrossRef]

24. Mollick, E. The dynamics of crowdfunding: An exploratory study. J. Bus. Ventur. 2014, 29, 1-16. [CrossRef]

25. Drover, W.; Wood, M.S.; Zacharakis, A. Attributes of angel and crowdfunded investments as determinants of VC screening decisions. Entrep. Theory Pract. 2017, 41, 323-347. [CrossRef]

26. Short, J.C.; Ketchen Jr, D.J.; McKenny, A.F.; Allison, T.H.; Ireland, R.D. Research on crowdfunding: Reviewing the (very recent) past and celebrating the present. Entrep. Theory Pract. 2017, 41, 149-160. [CrossRef]

27. Vismara, S. Equity retention and social network theory in equity crowdfunding. Small Bus. Econ. 2016, 46, 579-590. [CrossRef]

28. Estrin, S.; Gozman, D.; Khavul, S. Case study of the equity crowdfunding landscape in London: An entrepreneurial and regulatory perspective. FIRES Case Study 2016, 5, 1-62.

29. Agrawal, A.; Catalini, C.; Goldfarb, A. The Geography of Crowdfunding; National Bureau of Economic Research: Cambridge, MA, USA, 2011; Available online: https://www.nber.org/system/files/working_papers/w16820/w16820.pdf (accessed on 10 July 2019).

30. Fenwick, M.; McCahery, J.A.; Vermeulen, E.P. Fintech and the Financing of Entrepreneurs: From Crowdfunding to Marketplace Lending. 2017. Available online: https:/ / papers.ssrn.com/sol3/papers.cfm?abstract_id=2967891. (accessed on 13 July 2019).

31. Mollick, E.; Robb, A. Democratizing innovation and capital access: The role of crowdfunding. Calif. Manag. Rev. 2016, 58, 72-87. [CrossRef]

32. Cox, K.C.; Lortie, J.; Stewart, S.A. When to pray to the angels for funding: The seasonality of angel investing in new ventures. J. Bus. Ventur. Insights 2017, 7, 68-76. [CrossRef]

33. Mason, C.M.; Harrison, R.T. The size of the informal venture capital market in the United Kingdom. Small Bus. Econ. 2000, 15, 137-148. [CrossRef]

34. Becker-Blease, J.R.; Sohl, J.E. New venture legitimacy: The conditions for angel investors. Small Bus. Econ. 2015, 45, 735-749. [CrossRef]

35. Kerr, W.R.; Lerner, J.; Schoar, A. The consequences of entrepreneurial finance: Evidence from angel financings. Rev. Financ. Stud. 2011, 27, 20-55. [CrossRef]

36. Teker, S.; Teker, D. Venture capital and business angels: Turkish case. Procedia-Soc. Behav. Sci. 2016, 235, 630-637. [CrossRef]

37. Dibrova, A. Business angel investments: Risks and opportunities. Procedia-Soc. Behav. Sci. 2015, 207, 280-289. [CrossRef]

38. Puri, M.; Zarutskie, R. On the life cycle dynamics of venture-capital-and non-venture-capital-financed firms. J. Financ. 2012, 67, 2247-2293. [CrossRef]

39. Buchner, A.; Mohamed, A.; Wagner, N. Are venture capital and buyout backed IPOs any different? J. Int. Financ. Mark. Inst. Money 2019, 60, 39-49. [CrossRef]

40. Fernhaber, S.A.; McDougall-Covin, P.P. Venture capitalists as catalysts to new venture internationalization: The impact of their knowledge and reputation resources. Entrep. Theory Pract. 2009, 33, 277-295. [CrossRef]

41. Mäkelä, M.M.; Maula, M.V. Cross-border venture capital and new venture internationalization: An isomorphism perspective. Ventur. Cap. 2005, 7, 227-257. [CrossRef]

42. Bertoni, F.; Colombo, M.G.; Grilli, L. Venture capital financing and the growth of high-tech start-ups: Disentangling treatment from selection effects. Res. Policy 2011, 40, 1028-1043. [CrossRef]

43. Davila, A.; Foster, G.; Gupta, M. Venture capital financing and the growth of startup firms. J. Bus. Ventur. 2003, 18, 689-708. [CrossRef]

44. Guo, D.; Jiang, K. Venture capital investment and the performance of entrepreneurial firms: Evidence from China. J. Corp. Financ. 2013, 22, 375-395. [CrossRef]

45. Jain, B.A.; Kini, O. Venture capitalist participation and the post-issue operating performance of IPO firms. Manag. Decis. Econ. 1995, 16, 593-606. [CrossRef]

46. Cosh, A.; Cumming, D.; Hughes, A. Outside enterpreneurial capital. Econ. J. 2009, 119, 1494-1533. [CrossRef]

47. Vanacker, T.R.; Manigart, S. Pecking order and debt capacity considerations for high-growth companies seeking financing. Small Bus. Econ. 2010, 35, 53-69. [CrossRef]

48. Tsai, H.Y.; Chang, C.W.; Lin, H.L. "Fuzzy hierarchy sensitive with Delphi method to evaluate hospital organization performance". Expert Syst. Appl. 2010, 37, 5533-5541. [CrossRef]

49. Chen, H.C.; Yang, C.H. Applying a multiple criteria decision-making approach to establishing green marketing audit criteria. $J$. Clean. Prod. 2019, 210, 256-265. [CrossRef]

50. Lai, Y.L.; Ishizaka, A. The application of multi-criteria decision analysis methods into talent identification process: A social psychological perspective. J. Bus. Res. 2020, 109, 637-647. [CrossRef]

51. Mejías, A.M.; Bellas, R.; Pardo, J.E.; Paz, E. Traceability management systems and capacity building as new approaches for improving sustainability in the fashion multi-tier supply chain. Int. J. Prod. Econ. 2019, 217, 143-158. [CrossRef]

52. Van Le, H.; Suh, M.H. Changing trends in internet startup value propositions, from the perspective of the customer. Technol. Forecast. Soc. Chang. 2019, 146, 853-864.

53. Hsueh, J.T.; Lin, C.Y. Constructing a network model to rank the optimal strategy for implementing the sorting process in reverse logistics: Case study of photovoltaic industry. Clean Technol. Environ. Policy 2015, 17, 155-174. [CrossRef] 
54. Kheybari, S.; Rezaie, F.M.; Farazmand, H. Analytic network process: An overview of applications. Appl. Math. Comput. 2020, 367, 124780. [CrossRef]

55. Lin, C.S.; Lin, C.Y. Constructing a network evaluation framework for improving the financial ecosystem in small-medium size firms. Technol. Econ. Dev. Econ. 2018, 24, 893-913. [CrossRef]

56. Saaty, T.L. Decision Making with Dependence and Feedback: The Analytic Network Process; RWS Publications: online publisher, 1996; Volume 4922.

57. Rowe, G.; Wright, G. The Delphi technique as a forecasting tool: Issues and analysis. Int. J. Forecast. 1999, 15, 353-375. [CrossRef]

58. Saaty, T.L.; Takizawa, M. Dependence and independence: From linear hierarchies to nonlinear networks. Eur. J. Oper. Res. 1986, 26, 229-237. [CrossRef]

59. Dubey, N.; Tanksale, A. A study of barriers for adoption and growth of food banks in India using hybrid DEMATEL and Analytic Network Process. Socio-Econ. Plan. Sci. 2021, 101124. (In press) [CrossRef]

60. Keyvanfar, A.; Shafaghat, A.; Ismail, N.; Mohamad, S.; Ahmad, H. Multifunctional retention pond for stormwater management: A decision-support model using Analytical Network Process (ANP) and Global Sensitivity Analysis (GSA). Ecol. Indic. 2021, 124, 107317. [CrossRef]

61. Kordrostami, F.; Attarod, P.; Abbaspour, K.C.; Ludwig, R.; Etemad, V.; Alilou, H.; Bozorg-Haddad, O. Identification of optimum afforestation areas considering sustainable management of natural resources, using geo-environmental criteria. Ecol. Eng. 2021, 168, 106259. [CrossRef]

62. Wu, C.R.; Lin, C.T.; Chen, H.C. Evaluating competitive advantage of the location for Taiwanese hospitals. J. Inf. Optim. Sci. 2007, 28, 841-868. [CrossRef]

63. Sung, W.C. Application of Delphi Method, a Qualitative and Quantitative Analysis, to the Healthcare Management. J. Healthc. Manag. 2001, 2, 11-19.

64. Hasson, F.; Keeney, S. Enhancing rigour in the Delphi technique research. Technol. Forecast. Soc. Chang. 2011, 78, 1695-1704. [CrossRef]

65. Atmaca, E.; Basar, H.B. Evaluation of power plants in Turkey using Analytic Network Process (ANP). Energy 2012, 44, 555-563. [CrossRef]

66. Keramati, A.; Salehi, M. Website success comparison in the context of e-recruitment: An analytic network process (ANP) approach. Appl. Soft Comput. 2013, 13, 173-180. [CrossRef]

67. Ali-Yrkko, J.; Rouvinen, P.; Seppala, T.; Yla-Anttila, P. “Who Captures Value in Global Supply Chains? Case Nokia N95 Smartphone". J. Ind. Compet. Trade 2011, 11, 263-278. [CrossRef]

68. Linden, G.; Kraemer, K.L.; Dedrick, J. "Who Captures Value in a Global Innovation Network? The Case of Apple's iPod". Commun. ACM 2009, 52, 140-144. [CrossRef]

69. Mahmood, A.; Luffarelli, J.; Mukesh, M. What's in a logo? The impact of complex visual cues in equity crowdfunding. J. Bus. Ventur. 2019, 34, 41-62. [CrossRef]

70. Piva, E.; Rossi-Lamastra, C. Human capital signals and entrepreneurs' success in equity crowdfunding. Small Bus. Econ. 2018, 51, 667-686. [CrossRef]

71. Bapna, S. Complementarity of signals in early-stage equity investment decisions: Evidence from a randomized field experiment. Manag. Sci. 2019, 65, 933-952. [CrossRef]

72. Butticè, V.; Di Pietro, F.; Tenca, F. Is equity crowdfunding always good? Deal structure and the attraction of venture capital investors. J. Corp. Financ. 2020, 65, 101773. [CrossRef]

73. Hornuf, L.; Schmitt, M.; Stenzhorn, E. Equity crowdfunding in Germany and the United Kingdom: Follow-up funding and firm failure. Corp. Gov. An. Int. Rev. 2018, 26, 331-354. [CrossRef]

74. Signori, A.; Vismara, S. Does success bring success? The post-offering lives of equity-crowdfunded firms. J. Corp. Financ. 2018, 50, 575-591. [CrossRef] 